\title{
MODEL PEMBELAJARAN BERBASIS MASALAH DAN KEMAMPUAN PENALARAN MATEMATIKA SISWA PADA MATERI BARISAN DAN DERET ARITMETIKA
}

\author{
Novia Widiati $^{1}$, Syaifuddin ${ }^{2}$, Nyimas Inda Kusumawati ${ }^{3}$ \\ Universitas Muhammadiyah Palembang ${ }^{1,2,3}$ \\ nyimas.inda@gmail.com ${ }^{3}$
}

\begin{abstract}
ABSTRAK
Tujuan penelitian ini adalah untuk mengetahui pengaruh model pembelajaran berbasis masalah terhadap kemampuan penalaran matematika pada materi barisan dan deret aritmetika di kelas VIII SMP Patra Mandiri 2 Palembang. Penelitian ini menggunakan metode penelitian eksperimen dengan desain posttest only control design. Populasi dalam penelitian ini adalah seluruh siswa kelas VIII SMP Patra Mandiri 2 Palembang tahun ajaran 2018/2019 yang berjumlah 3 kelas. Sampel diambil dengan melakukan acak kelas, dan terpilih kelas VIII.A sebagai kelas eksperimen dan kelas VIII.B sebagai kelas kontrol. Teknik pengumpulan data dalam penelitian ini berupa tes tertulis tentang kemampuan penalaran matematika. Data dianalisis secara deskriptif kuantitatif, uji statistik yang dilakukan adalah uji t. Hasil analisis data menunjukkan bahwa terdapat pengaruh model pembelajaran berbasis masalah terhadap kemampuan penalaran matematika pada materi barisan dan deret aritmatika di kelas VIII SMP Patra Mandiri 2 Palembang.
\end{abstract}

Kata kunci : penalaran matematika, pembelajaran berbasis masalah

\begin{abstract}
This study aims to determine the effect of problem-based learning models on the ability of mathematical reasoning on arithmetic sequences and series in class VIII SMP Patra Mandiri 2 Palembang. This study used an experimental research method with post-test only control design. The population in this study were all students of class VIII SMP Patra Mandiri 2 Palembang in the 2018/2019 school year, amounting to 3 classes. Samples were taken by doing a random class, and selected class VIII.A as an experimental class and class VIII.B as a control class. Data collection techniques in this study were written tests of mathematical reasoning abilities. Data were analyzed descriptively quantitatively, the statistical test conducted was the t-test. The results of the data analysis show that there is an influence of the problem-based learning model on the ability of mathematical reasoning on arithmetic sequences and series in class VIII SMP Patra Mandiri 2 Palembang.
\end{abstract}

Keywords : mathematical reasoning, problem based learning 


\section{PENDAHULUAN}

Matematika memiliki peran penting dalam kehidupan manusia. Banyak aktivitas kehidupan yang bersentuhan dengan matematika, mulai dari aktivitas yang sederhana sampai kepada aktivitas yang rumit, mulai dari masyarakat awam sampai kepada ilmuwan. Dapat dikatakan bahwa matematika diperlukan di berbagai bidang kehidupan.

Walaupun matematika diperlukan di berbagai bidang, namun matematika adalah ilmu yang berdiri sendiri dan semuanya berkenaan dengan ide-ide atau konsep-konsep abstrak yang tersusun secara hirarkis. Matematika merupakan ide-ide yang berisi simbol-simbol dan konsep-konsep abstrak, jadi konsep-konsep matematika harus dipahami terlebih dahulu sebelum memanipulasi simbol-simbol (Susanto, 2013:183). Dan, hal ini perlu ditekankan pada saat pembelajaran matematika itu sendiri.

Pemahaman matematika siswa akan semakin dalam, jika siswa dapat mengaitkan matematika yang mereka pelajari di sekolah dengan penerapannya di kehidupan sehari-hari. Apabila siswa merasakan keterkaitan matematika dengan kehidupannya, pasti siswa merasakan kegunaan matematika dan mereka berusaha untuk mempelajarinya.

Konsep matematika tidak dapat dipelajari dengan baik jika hanya memindahkan materi dari guru ke siswa. Pembelajaran teacher oriented, biasanya menjadikan siswa hanya memperoleh ilmu dari apa yang disampaikan oleh guru, tapi siswa menjadi pasif dan tidak kreatif. Konsep matematika akan mudah diserap dengan baik jika siswa dilatih untuk menggunakan penalarannya dan memecahkan masalah.

Penalaran memiliki peran penting sebagai kemampuan dasar matematika. Sebagaimana yang diungkapkan oleh Ansjar dan Sembiring (Rohana dan Ningsih, 2019) bahwa kegiatan mempelajari matematika, mengembangkan atau menyelesaikan permasalahan matematika tidak dapat dipisahkan dari kegiatan penalaran. Penalaran merupakan suatu proses berpikir yang dilakukan oleh manusia dengan menghubungkan data dan fakta, sehingga mendapatkan suatu kesimpulan. Data dan fakta akan melalui proses berpikir manusia yang akan dinalar benar atau tidaknya (Hudaa, 2018:169).

Penalaran adalah proses berpikir yang menggunakan argumen, pertanyaan, premis, atau aksioma untuk menentukan benar-salahnya suatu simpulan. Hal ini sesuai dengan pendapat Latif (2014:261) yang menyatakan penalaran bersifat logis, jika kesimpulan yang dihasilkan dari argumen atau premis yang salah akan menghasilkan penalaran yang tidak logis.

Jika siswa diberi kesempatan untuk menggunakan keterampilan bernalar, untuk menyelesaikan suatu permasalahan dengan pengetahuan yang dimiliki siswa sendiri, maka guru harus bisa mengarahkan siswa untuk dapat mengembangkan kemampuan penalaran matematika pada siswa.

Evaluasi tentang kemampuan matematis termasuk kemampuan penalaran matematis sudah banyak dilakukan, salah satunya adalah program PISA. PISA (Programme for International Student Assessment) merupakan penilaian yang dilakukan secara internasional dengan cakupan penilaian membaca, matematika dan sains. Hasil penilaian PISA yang dilakukan menunjukkan bahwa kemampuan matematika siswa Indonesia pada tahun 2018 berada pada peringkat ke 72 dari 78 negara peserta (Harususilo, 2019). Lemahnya kemampuan matematis termasuk 
kemampuan penalaran pada siswa dapat terjadi karena siswa hanya terbiasa mengerjakan soal rutin yang dicontohkan oleh guru. Oleh karena itu, jika dihadapkan dengan permasalahan atau soal matematika yang lebih kompleks, maka siswa akan kesulitan mengerjakannya.

Begitu juga halnya dengan kemampuan penalaran matematis siswa kelas VIII SMP Patra Mandiri 2 Palembang, masih banyak siswa yang kemampuan penalarannya masih kurang baik. Dari keterangan yang diberikan guru matematikanya, siswa agak susah mengikuti pembelajaran untuk materi yang membutuhkan penalaran tinggi. Apalagi dari indikator-indikator penalaran yang diacu, kemampuan penalaran termasuk dalam kategori tinggi. Dengan demikian, kemampuan penalaran matematis siswa kelas VIII SMP Patra Mandiri 2 Palembang perlu ditingkatkan.

Meningkatkan kemampuan penalaran matematika dapat dicoba dengan menerapkan model pembelajaran yang dapat memudahkan siswa untuk mengembangkan daya nalar yang baik, yaitu model Pembelajaran Berbasis Masalah (PBM). Model PBM merupakan kurikulum sekaligus proses. Kurikulum meliputi masalah-masalah yang dipilih dan dirancang dengan cermat yang menuntut upaya kritis siswa untuk memperoleh pengetahuan, menyelesaikan masalah, belajar secara mandiri, dan memiliki skill partisipasi yang baik (Huda, 2014:272).

Model PBM dapat meningkatkan berpikir kreatif dan aktivitas belajar siswa. Model PBM menitikberatkan pada adanya suatu permasalahan yang siswa hadapi dalam pembelajaran. Permasalahan dijadikan sebagai titik awal dalam membangun konsep (Isrok'atun dan Rosmala, 2018:43). Dalam pembelajaran matematika, siswa diberi suatu masalah kehidupan seputar konsep matematika. Model PBM adalah suatu model pembelajaran yang menuntut siswa untuk berpikir kritis, memecahkan masalah, belajar secara mandiri, dan menuntut keterampilan berpartisipasi dalam tim (Riyanto, 2010:285). Model ini dapat melatih dan mengembangkan kemampuan untuk menyelesaikan masalah yang berorientasi pada masalah autentik dari kehidupan aktual siswa, untuk merangsang kemampuan berpikir tingkat tinggi (Shoimin, 2014:129).

Model PBM merupakan model pembelajaran yang terdiri atas tahapan sebagai berikut (Rusman, 2014): (1) Orientasi siswa pada masalah, (2) Mengorganisasi siswa untuk belajar, (3) Mengembangkan dan menyajikan hasil karya, dan (4) Menganalisis dan mengevaluasi proses pemecahan masalah. Pada tahap awal siswa diajak untuk memecahkan masalah yang telah disediakan. Gick dan Holyoak (Sumartini, 2015) menyebutkan bahwa pada tahap siswa menjadi lebih termotivasi untuk belajar karena mereka harus terlibat aktif dalam pembelajaran dan harus melakukan penyelidikan lebih lanjut dalam upaya untuk memahami masalah, mengidentifikasi masalah dan berusaha untuk menyelesaikannya.

Berdasarkan penelitian yang telah dilakukan, diketahui bahwa model PBM berpengaruh terhadap kemampuan pemecahan masalah matematis siswa (Al Ayubi, Erwanudin, dan Bernard, 2018; Masri, Suyono, dan Deniyanti, 2018). Model ini diidentifikasi dapat meningkatkan pemahaman konsep matematis siswa dalam mempelajari topik Sistem Persamaan Linier Dua Variabel (SPLDV).

Melihat keunggulan yang dapat diperoleh dari penerapan model PBM ini, perlu dikaji pengaruh model ini terhadap kemampuan penalaran matematis siswa SMP kelas VIII pada materi barisan dan deret aritmetik. Tujuan penelitian ini adalah untuk 
mengetahui pengaruh model PBM terhadap kemampuan penalaran matematis siswa kelas VIII SMP Patra Mandiri 2 Palembang.

\section{METODE}

Penelitian ini menggunakan metode penelitian eksperimen. Rancangan yang digunakan yaitu post-test only control design yaitu suatu penelitian yang dilaksanakan dengan menggunakan dua kelompok yang masing-masing kelompok dipilih secara random, kelas yang diajarkan menggunakan model pembelajaran berbasis masalah disebut kelas eksperimen dan kelas yang diajarkan tanpa menggunakan model pembelajaran berbasis masalah disebut kelas kontrol.

Tabel 1. Rancangan penelitian

\begin{tabular}{|c|c|c|c|}
\hline $\mathrm{E}$ & $\mathrm{R}$ & $\mathrm{X}$ & $\mathrm{X}_{1}$ \\
\hline $\mathrm{K}$ & $\mathrm{R}$ & - & $\mathrm{X}_{2}$ \\
\hline
\end{tabular}

(Sugiyono, 2015:112)

Keterangan:

E : Kelompok eksperimen yang diambil secara random

$\mathrm{K}$ : Kelompok kontrol yang diambil secara random

$\mathrm{X}$ : Perlakuan

$\mathrm{X}_{1}$ : Kemampuan penalaran matematika kelas eksperimen

$\mathrm{X}_{2}$ : Kemampuan penalaran matematika kelas kontrol

Populasi dalam penelitian ini adalah seluruh siswa kelas VIII SMP Patra Mandiri 2 Palembang tahun ajaran 2018/2019 yang berjumlah 3 kelas. Sampel diambil dengan melakukan acak kelas, dan terpilih kelas VIII.A sebagai kelas eksperimen dan kelas VIII.B sebagai kelas kontrol.

Indikator kemampuan penalaran matematis siswa yang dikaji dalam penelitian merujuk pada Peraturan Dirjen Dikdasmen No.506/C/PP/2004 (Wardhani, 2008:14), yaitu : (1) Menemukan pola atau sifat dari gejala matematis untuk membuat generalisasi, (2) Mengajukan dugaan, (3) Menarik kesimpulan, menyusun bukti, memberikan alasan atau bukti terhadap kebenaran solusi, (4) Melakukan manipulasi matematika, (5) Menarik kesimpulan dan pernyataan, dan (6) Memeriksa kesahihan suatu argumen.

Data dikumpulkan melalui tes. Tes yang digunakan adalah tes berbentuk esai (uraian) yang berjumlah tiga soal. Tujuan dilakukan tes tersebut adalah untuk melihat kemampuan penalaran matematika siswa setelah mengikuti pelajaran. Data dalam penelitian ini dianalisis dengan menggunakan uji normalitas, uji homogenitas, dan uji t untuk dua sampel bebas.

\section{HASIL DAN PEMBAHASAN}

Penelitian ini dilaksanakan dalam 4 kali pertemuan baik di kelas kontrol maupun di kelas eksperimen, terdiri dari 3 kali kegiatan pembelajaran dan 1 kali pertemuan tes akhir. Setiap pertemuan berlangsung 80 menit ( 2 jam pelajaran) atau 2 x 40 menit. Proses pelaksanaan pembelajaran di kelas eksperimen menggunakan 
model PBM merujuk pada Ibrahim dan Nur (Rusman, 2014) yang dapat dilihat pada tabel 2 berikut ini.

Tabel 2. Deskripsi pelaksanaan pembelajaran PBM

\begin{tabular}{|c|c|c|}
\hline Fase & Indikator & Tingkah laku guru \\
\hline 1 & $\begin{array}{l}\text { Orientasi siswa pada } \\
\text { masalah }\end{array}$ & $\begin{array}{l}\text { Guru menjelaskan tujuan pembelajaran yang ingin } \\
\text { dicapai yaitu siswa diharapkan dapat menyelesaikan } \\
\text { soal-soal yang berhubungan dengan materi barisan } \\
\text { dan deret aritmetika. }\end{array}$ \\
\hline 2 & $\begin{array}{l}\text { Mengorganisasi siswa untuk } \\
\text { belajar }\end{array}$ & $\begin{array}{l}\text { Guru membagi kelompok pada kelas eksperimen } \\
\text { menjadi } 5 \text { kelompok yang setiap kelompok terdiri } \\
\text { dari } 4 \text { siswa. Memberikan LKS berupa permasalahan } \\
\text { yang mengenai materi barisan dan deret aritmetika }\end{array}$ \\
\hline 3 & $\begin{array}{l}\text { Mengembangkan dan } \\
\text { menyajikan hasil karya }\end{array}$ & $\begin{array}{l}\text { Guru mengajak siswa untuk mendiskusikan masalah } \\
\text { yang diberikan, mengingatkan untuk menuliskan apa } \\
\text { yang diketahui dan apa yang ditanya sebelum } \\
\text { menjawab soal, serta mempresentasikan hasil } \\
\text { diskusinya di depan kelas. }\end{array}$ \\
\hline 4 & $\begin{array}{l}\text { Menganalisis dan } \\
\text { mengevaluasi proses } \\
\text { pemecahan masalah }\end{array}$ & $\begin{array}{l}\text { Guru melakukan refleksi dengan menanyakan } \\
\text { kepada siswa tentang materi yang belum dipahami } \\
\text { dengan baik, lalu membahasnya di depan kelas. Guru } \\
\text { membimbing siswa untuk memberikan kesimpulan } \\
\text { dengan benar tentang materi yang telah dipelajari. } \\
\text { Guru memberikan soal-soal latihan kepada siswa } \\
\text { untuk melihat kemampuan penalaran matematis } \\
\text { siswa serta menginformasikan materi yang akan } \\
\text { dipelajari pada pertemuan selanjutnya }\end{array}$ \\
\hline
\end{tabular}

Guru memberikan masalah berupa soal-soal materi barisan dan deret aritmatika yang biasa ditemui dalam kehidupan sehari-hari. Soal diberikan dalam bentuk LKS yang dikerjakan secara berkelompok. Beberapa siswa yang merasa kesulitan memberikan pertanyaan pada guru. Kesulitan yang dialami siswa adalah dalam menginterpretasikan soal, sehingga guru meminta siswa untuk melakukan simulasi sederhana dalam mengartikan soal agar lebih dipahami maksudnya.

Salah satu soal yang diberikan adalah "Seorang penguasaha roti memasok hasil produksinya pada sebuah toko roti. Setiap minggunya selalu ada penambahan permintaan. Pada minggu pertama memasok 1000 roti, minggu kedua 1.100 roti, minggu ketiga 1200 roti, dan seterusnya sehingga mengikuti barisan aritmetika. Tulislah 3 suku pertama barisan aritmetika? Tentukanlah pola dari urutan pertama, kedua dan selanjutnya!" Soal ini mengarahkan siswa untuk menjawab secara terurut dan menggeneralisasi. Siswa diminta mengurutkan dulu tiga suku pertama yang mereka peroleh, kemudian baru mencari polanya.

Langkah selanjutnya, siswa menentukan dugaan terhadap beda antar suku serta menduga suku-suku berikutnya. Siswa kemudian membuat kesimpulan sementara dalam menentukan suku ke-n dan melakukan pembuktian. Hasil diskusi mengarahkan siswa untuk mampu memberikan alasan terhadap pembuktian yang 
sudah mereka lakukan dan mengujicobakannya kembali (manipulasi matematika). Terakhir, siswa menarik kesimpulan akhir dan memeriksa kesahihannya.

Hal yang paling sulit adalah ketika menentukan rumus. Guru mengarahkan siswa dalam berdiskusi untuk menemukan 'beda' antar suku, menerka suku berikutnya dan menuliskan ilustrasinya. Dari pembelajaran PBM ini siswa mampu menemukan karakteristik dari suku pertama dan beda antar suku. Dan di akhir pembelajaran siswa mampu menemukan rumusnya sendiri.

Selesai berdiskusi, guru meminta salah satu kelompok untuk maju dan mempresentasikan hasil diskusinya. Ternyata tidak semua jawaban tiap kelompok sama. Beberapa kelompok memberikan pendapatnya, sehingga diskusi berjalan aktif. Guru meminta kelompok lain untuk memaparkan hasil diskusi. Sehingga akhirnya diperoleh jawaban yang paling tepat. Presentasi dilakukan kembali untuk soal lain. Pada tahap ini berjalan lebih lancar karena siswa sudah mulai paham dari hasil diskusi pertama. Di akhir diskusi, guru menunjuk beberapa siswa untuk menyimpulkan hasil diskusi dan memaparkan temuan rumus yang mereka peroleh.

Pada pertemuan berikutnya, guru memberikan soal latihan yang dikerjakan secara individu. Beberapa siswa masih harus diarahkan dalam menjawab soal. Sebagian siswa masih lupa menuliskan apa yang diketahui dan apa yang ditanyakan. Guru mengingatkan kembali langkah menjawab soal serta pada proses temuan rumus yang telah mereka lakukan sebelumnya.

Jadi, dapat dinyatakan bahwa model pembelajaran berbasis masalah adalah suatu model pembelajaran yang menuntut siswa untuk belajar kreatif, menyelidiki masalah yang ada, menemukan permasalahan. Kemudian menyelesaikan suatu masalah dengan baik. Siswa diajarkan bagaimana cara bekerjasama dalam satu kelompok, berdiskusi, mendorong teman lain untuk bekerja sama, dan menghargai pendapat teman. Sehingga semua siswa dapat mengembangkan kemampuan penalaran dalam memahami permasalahan yang diselesaikan dalam kelompok dan dapat meningkatkan kemampuan penalaran matematika.

Pembelajaran di kelas kontrol tanpa menggunakan model PBM. Seperti pembelajaran yang biasa dilakukan, guru menjelaskan materi dan memberikan rumus barisan dan deret aritmatika, memberikan contoh soal dan latihan. Latihan dilakukan dalam dua tahap, yaitu latihan berkelompok dan latihan individu. Guru melakukan tanya jawab, setiap latihan selesai. Beberapa siswa tampak terkendala saat menemukan soal cerita. Siswa kesulitan mengartikan soal cerita dan mengubahnya ke dalam rumus. Guru mengarahkan siswa untuk membaca alur cerita lebih teliti.

Postes dilaksanakan setelah pembelajaran tentang materi barisan dan deret aritmetika selesai. Hasil postes tentang kemampuan penalaran matematis untuk kelas eksperimen dan kelas kontrol dapat dilihat pada tabel 3. Rata-rata nilai kemampuan penalaran matematis siswa yang belajar dengan model PBM lebih besar dari siswa yang tidak menggunakan PBM. Untuk mengetahui pengaruh model PBM terhadap kemampuan penalaran matematis siswa, maka analisis data dilanjutkan dengan melakukan uji statistik inferensia. Dilakukan uji normalitas dan uji homogenitas varian dari dua kelas sampel, hasilnya dapat dilihat pada tabel 4 dan tabel 5. 
Tabel 3. Data kemampuan penalaran matematis

\begin{tabular}{ccccc}
\hline Kelas & Minimum & Maksimum & Rata-rata & $\begin{array}{c}\text { Simpangan } \\
\text { baku }\end{array}$ \\
\hline Eksperimen & 60,87 & 93,48 & 75,84 & 7,72 \\
Kontrol & 47,82 & 78,26 & 61,36 & 9,02 \\
\hline
\end{tabular}

Tabel 4. Uji normalitas data kemampuan penalaran matematis

\begin{tabular}{cccccc}
\hline & Kelas & Stat. & Sig. & Kesimpulan & Hasil \\
\hline $\begin{array}{c}\text { Kemampuan } \\
\text { Penalaran } \\
\text { Matematis }\end{array}$ & Eksperimen & 0,201 & 0,033 & $\begin{array}{c}\mathrm{H}_{0} \text { diterima, Ha } \\
\text { ditolak }\end{array}$ & Normal \\
\cline { 2 - 6 } & Kontrol & 0,154 & 0,200 & $\begin{array}{c}\mathrm{H}_{0} \text { diterima, Ha } \\
\text { ditolak }\end{array}$ & Normal \\
\hline
\end{tabular}

Tabel 5. Uji homogenitas varian

\begin{tabular}{cccc}
\hline Levene Statistic & df1 & df2 & Sig. \\
\hline 2.515 & 1 & 38 & .121 \\
\hline
\end{tabular}

Dari hasil uji prasyarat diketahui bahwa data kemampuan penalaran matematis siswa berdistribusi normal dan varian data dari dua kelas sampel homogen. Oleh karena itu analisis data dilanjutkan dengan menggunakan uji t untuk dua sampel bebas. Hasil uji t dapat dilihat pada tabel 6 berikut ini.

Tabel 6. Uji t untuk dua sampel bebas

\begin{tabular}{ccccc}
\hline Kelas & $\mathrm{n}$ & $\mathrm{t}$ & Sig. & Kesimpulan \\
\hline Eksperimen & 20 & \multirow{2}{*}{5,454} & 0,000 & \multirow{2}{*}{$\mathrm{H}_{0}$ ditolak } \\
\hline Kontrol & 20 & & & \\
\hline
\end{tabular}

Pengujian hipotesis dilakukan dengan uji dua pihak. Kriteria pengujian adalah tolak $\mathrm{H}_{0}$ jika nilai sig. lebih kecil dari 0,025. Berdasarkan tabel 6 diketahui bahwa nilai sig. lebih kecil dari 0.025 , sehingga dapat dikatakan bahwa $\mathrm{H}_{0}$ ditolak. Hal ini menunjukkan bahwa terdapat perbedaan rata-rata kemampuan penalaran matematis antara kelas eksperimen dan kelas kontrol. Dengan demikian dapat ditarik kesimpulan bahwa ada pengaruh model PBM terhadap kemampuan penalaran matematis siswa kelas VIII SMP Patra Mandiri 2 Palembang.

Siswa di kelas eksperimen, setelah melakukan pembelajaran model PBM lebih terbiasa melakukan penalaran matematis dalam mengolah pernyataan dan pertanyaan dalam soal-soal cerita barisan dan deret aritmatika. Karenanya, siswa tidak mengalami kesulitan yang berarti dalam menterjemahkan soal cerita dan mengubahnya ke dalam rumus. Sedangkan, siswa di kelas kontrol, hanya terpaku pada rumus baku yang mereka pahami. Saat menemukan soal baru, siswa kesulitan menempatkan rumus. Penalaran matematis siswa di kelas kontrol tidak sebaik siswa di kelas eksperimen.

Berdasarkan hasil analisis data, diketahui bahwa model PBM berpengaruh terhadap kemampuan penalaran matematis siswa pada materi barisan dan deret aritmetika. Hal ini sejalan dengan penelitian sebelumnya seperti penelitian Masri, Suyono, dan Deniyanti (2018) dan penelitian Al Ayubi, Erwanudin, dan Bernard (2018). 
Pelaksanaan model PBM ini guru bertindak sebagai motivator, namun masalah yang telah direncanakan dapat membantu untuk meningkatkan berpikir kognitif siswa. Hal ini senada dengan pernyataan yang diungkapkan oleh Rusman (2014) bahwa proses pemecahan masalah dalam model PBM ini menuntut siswa untuk berpikir secara menyeluruh, sistematik, logis, analitis, dan kreatif. Kemampuan berpikir seperti ini merupakan kemampuan yang terintegrasi dengan kemampuan penalaran.

\section{SIMPULAN DAN SARAN}

Berdasarkan hasil penelitian dan pembahasan di atas terlihat bahwa ada pengaruh model PBM terhadap kemampuan penalaran matematis siswa kelas VIII SMP Patra Mandiri 2 Palembang. Model PBM diterapkan dalam pembelajaran materi barisan dan deret aritmetik. Pada pelaksanaan model PBM ini siswa dihadapkan pada permasalahan dunia nyata yang berkaitan dengan materi barisan dan deret aritmetik. Kemudian secara berkelompok siswa bekerja sama untuk belajar memecahkan masalah. Guru melakukan bimbingan terhadap siswa yang mengalami kesulitan. Siswa juga memperoleh kesempatan untuk menyajikan hasil kerja mereka, melakukan diskusi kelas dan sebagai penutup bersama dengan guru melakukan refleksi terhadap proses pembelajaran.

Saran yang dapat disampaikan terkait hasil penelitian ini adalah bahwa model PBM dapat digunakan oleh peneliti lain dalam meningkatkan kemampuan berpikir matematis yang lain.

\section{DAFTAR PUSTAKA}

Al Ayubi, I.I., Erwanudin, dan Bernard. 2018. Pengaruh Pembelajaran Berbasis Masalah Terhadap Kemampuan Pemecahan Masalah Matematis Siswa SMA. JPMI (Jurnal Pembelajaran Matematika Inovatif), Vol. 1(3) : 355-360.

Harususilo, Y.E. Skor PISA 2018: Daftar Peringkat Kemampuan Matematika, Berapa Rapor Indonesia? Kompas.com, 7 Desember 2019 hal.1. [Online]. Tersedia : https://edukasi.kompas.com/read/2019/12/07/09425411/skor-pisa2018-daftar-peringkat-kemampuan-matematika-berapa-rapor-indonesia.

Huda, M. 2014. Model-model Pengajaran dan Pembelajaran. Yogyakarta: Pustaka Pelajar.

Hudaa, S. 2018. Estetika Berbahasa: Mengapresiasi Bahasa Indonesia. Sukabumi: CV Jejak Publisher.

Isrok'atun dan Rosmala, A. 2018. Model-model Pembelajaran Matematika. Jakarta: PT Bumi Aksara.

Latif, M. 2014. Filsafat Ilmu: Orientasi ke Arah Pemahaman. Jakarta: Kencana Prenada Media Group.

Masri, M.F., Suyono, dan Deniyanti, P. 2018. Pengaruh Metode Pembelajaran Berbasis Masalah Terhadap Self-Efficacy dan Kemampuan Pemecahan Masalah Matematis Ditinjau dari Kemampuan Awal Matematika Siswa SMA. JPPM (Jurnal Penelitian dan Pembelajaran Matematika), Vol. 11(1) : 116126.

Riyanto, Y. 2010. Paradigma Baru Pembelajaran. Jakarta: Prenada Media Group. 
Rohana dan Ningsih, Y.L. 2019. Peningkatan Kemampuan Penalaran Matematis Mahasiswa Melalui Pembelajaran Reflektif Berbantuan Aplikasi Moodle. Jurnal Indiktika, Vol. 1(2) : 134-143.

Rusman. 2014. Model-model Pembelajaran Mengembangkan Profesionalisme Guru. Jakarta: RajaGrafindo Persada.

Shoimin, A. 2014. 68 Model Pembelajaran Inovatif dalam Kurikulum 2013. Yogyakarta: Ar-Ruzz Media.

Sugiyono. 2015. Metode Penelitian Kuantitatif Kualitatif dan $R \&$ D. Bandung: Alfabeta.

Sumartini, T. S. 2015. Peningkatan Kemampuan Penalaran Matematis Siswa Melalui Pembelajaran Berbasis Masalah. Mosharafa Jurnal Pendidikan Matematika, Vol. 4(1) : 1-10.

Susanto, A. 2013. Teori Belajar \& Pembelajaran di Sekolah Dasar. Jakarta: Prenada Media Group.

Wardhani, S. 2008. Analisis SI dan SKL Mata Pelajaran Matematika SMP/MTs untuk Optimalisasi Pencapaian Tujuan. Yogyakarta: Pusat Pengembangan dan Pemberdayaan Pendidik dan Tenaga Kependidikan Matematika. 